\title{
The Albanian ENFORCEMENT SySTEM
}

Accepted
08. 10. 2020
Revised
10. 02. 2021
Published
30. 06. 2021

Keywords

enforcement

title,

enforcement

order,

mandatory

enforcement,

voluntary

enforcement,

means of

challenge

\author{
FLUTURA KOLA \\ University of Tirana, Faculty of Law, Tirana, Albania \\ E-mail: tafajf@yahoo.com
}

\section{CORRESPONDING AUTHOR}

tafajf@yahoo.com

\begin{abstract}
This article presents an overview of the Albanian legal system of enforcement in the civil and commercial area. Its purpose is not only to identify the enforcement system in Albania and the characteristics of each enforcement title but also to compare it with that of the Brussels IA Regulation. The article concludes that the Albanian enforcement system is built on the spirit of the European system and is very similar to several European countries. However, the range of foreign enforcement titles that can be recognized and enforced in Albania is narrower than that provided in the European Union countries. Therefore, it should be expanded to include, in addition to irreversible judgments, other European enforcement acts, such as European Payment Order, Settlement Agreements, Authentic instruments, etc.
\end{abstract}




\section{Enforceable acts according to the Albanian legal order}

Enforceable acts are those that are considered "enforcement titles" under Albanian law. The Albanian legislation does not explicitly define the "enforcement title." According to the case law, an enforcement title is a final act that shows the recognition of the full, precise, defined obligation of one person or entity against another under the provisions of the law. ${ }^{1}$ As per a Unifying Judgment of the Albanian High Court, ${ }^{2}$ "enforcement titles" are mainly judgments, as well as, in exceptional cases, other acts expressly provided for in the Albanian Civil Procedure Code (hereinafter: ACPC), or in special laws, which, by virtue of their enforcement power, are equated for all effects with irreversible judgments."

Articles 510 and 511 of the ACPC provide a list of enforcement titles, which include the following:

1. irreversible/peremptory civil judgments containing an obligation;

2. decisions on interim measures;

3. judgments on temporary enforcement;

4. judgments on fines imposed by the court;

5. judgments on the mandatory taking of evidence;

6. judgments on the part ordering the costs of the proceedings;

7. irreversible/peremptory criminal judgments in the part dealing with property rights;

8. foreign judgments that are recognized in the Republic of Albania (hereinafter: RoA) in accordance with the provisions of the ACPC;

9. foreign arbitral awards that are recognized in the RoA;

10. arbitral awards issued in the RoA;

11. notarial deeds containing monetary obligations;

12. documents for granting bank loans or documents for granting loans from non-banking financial institutions;

13. bills of exchange, cheques, and order papers equivalent to them;

\footnotetext{
${ }^{1}$ Judgment of the Civil Chamber of the High Court No. 169, dated 05.03.2013, para. 20.

2 Unifying Judgment of the Albanian High Court No. 980, dated 29.09.2000.
} 
14. other documents that are considered enforcement titles and the enforcement officer is authorised to enforce them according to specific laws.

The meaning and some characteristics of each of these enforcement titles are elaborated in the following sub-sections.

\subsection{Irreversible/peremptory civil judgments containing an obligation, decisions on interim measures and judgments on temporary enforcement}

Final judgments (vendime përfundimtare) are those that settle the case on the merits and are rendered by the court at the end of the proceedings (Article 126 ACPC). These judgments become enforcement titles only when two conditions are cumulatively meet: First, the final judgment becomes irreversible/peremptory (vendim i formës së prere). Second, the final judgment is condemnatory and not merely declaratory. The judgment of the court becomes irreversible when: a) it cannot be appealed at the Appellate Court; b) no appeal has been made against it within the time limits determined by law or the appeal has been withdrawn; c) the appeal presented has not been accepted; d) the judgment (of the first instance) is upheld, is changed, or the case is dismissed in the court of the second instance (appeal court) (Article 451 ACPC).

Exceptionally, even when the first condition is not met, a final judgment is an enforcement title when it is rendered on temporary enforcement (Article 510/a ACPC). The judgment of the court may be issued on temporary enforcement when it has decided on: a) a maintenance obligation; b) on the retribution for work; c) on the return of possession of the conjugal place of residence. The judgment may also be issued on temporary enforcement when due to the delay of enforcement, the Claimant may suffer significant damage, which cannot be remedied, or when the enforcement of the judgment would become impossible or would be made exceedingly difficult. 
A final judgment of a declarative nature cannot be considered an enforcement title since it does not meet one of the above-mentioned criteria that the final judgment should be condemnatory but may serve as a basis for the later issuing of a binding judgment.

A settlement between the parties becomes a court settlement once the judge approves it. According to Article 158/ç (1)(2) ACPC, the judge shall make every effort to settle the dispute amicably during the preparatory stage, when the nature of the case allows that. The judge, where appropriate, shall order the parties involved to appear before the court. At each stage of the trial, the court shall inform the parties about the possibility of settlement of the dispute through mediation and, if they give their consent, it transfers the case to mediation. The prerequisites for the conclusion of a court settlement are as follows: a) The dispute must be of a civil, commercial, family, labour, intellectual property, or consumer rights nature. ${ }^{3}$ b) The settlement must not be contrary to the law. ${ }^{4}$ The court settlement binds the parties in the same way as other judgments and becomes enforceable in the same way as a final judgment. Thus, if neither party exercises the right of appeal or the appeal is not accepted by the court, or the judgment of the first instance on the court settlement is upheld by the court of appeal, a court settlement becomes enforceable.

Furthermore, interim judgments on security measures, judgments on temporary enforcement, judgments on fines imposed by the court, judgments on the mandatory taking of evidence, and judgments on the part ordering court costs are considered enforcement titles according to Article 510/a and 511/2 of the ACPC. Unlike irreversible judgments, they are enforced directly by the enforcement officer without issuing an enforcement order.

\footnotetext{
${ }^{3}$ Article 2, para. 2 of the Law No. 10 385, dated 24.2.2011 "For mediation on solving disputes" amended lately by the Law No. 26/2018, provides that mediation is also applicable to disputes between public administration bodies and private persons. Mediation in the criminal field applies to disputes examined by the court at the request of the accused, victim, or at the request of the injured party, according to Articles 59 and 284 of the Code of Criminal Procedure, as well as in any case where special law allows it. The provisions of the Juvenile Justice Code apply to mediation in juvenile delinquency.

${ }^{4}$ Article 158 /ç para. 5 of ACPC.
} 


\subsubsection{Albanian judgments in conformity with the euro-autonomous definitions of "Judgment" elaborated by the Court of Justice of the European Union for the purposes of B IA}

For the purposes of the Brussels Ia Regulation (hereinafter: B IA), "judgment" means any judgment given by a court or tribunal of a Member State, whatever the judgment may be called, including a decree, order, decision, or writ of execution, as well as a decision on the determination of costs or expenses by an officer of the court (Article 2 of the B IA). For the purposes of Chapter III of B IA, "judgment" includes provisional measures ordered by a court or tribunal that under B IA has jurisdiction regarding the substance of the matter. In Solo Kleinmotoren $v$ Boch, the Court of Justice of the European Union (hereinafter: CJEU) defined a judgment, for the purpose of the B IA, as a decision emanating from a judicial body of a Member State, deciding on its own authority on the issues between the parties. Thus, the concept excludes a court settlement, even if it was reached in a court of a Member State and brings legal proceedings to an end since such settlements are essentially contractual in that their terms depend primarily on the parties' intention (Stone, 2018: p. 327; Magnus, Mankowski, 2016: p. 920). It also extends to a judgment by which the court of a Member State declines jurisdiction by virtue of a jurisdiction clause, so that on recognition, the court addressed is bound by the finding of the court of origin as to the validity of the clause.

Albanian judgments which are in conformity with the definition of "Judgment" elaborated by the Court of Justice of the European Union for the purposes of B IA are:

i. $\quad$ Final judgments of the civil courts on the merit of the case (Vendime përfundimtare)

ii. Civil courts judgments on provisional measures (except decisions on provisional measures issued by the courts that do not have jurisdiction/competence to adjudicate the merit of the case and those that are taken exparte) (Vendime për masa sigurimi)

iii. Civil court judgments on temporary enforcement (Vendime me ekzekutim të përkobshëm)

iv. Civil courts judgments on the part ordering costs of the proceedings (Vendime civile të forms së prerë në pjesën që urdhërojnë shpenzimet ġjqësore) 
v. Criminal judgments in the section on property rights (Vendime penale të formës së prerë në pjesën që bëjnë fjalëpër të drejta pasurore).

A court settlement, under the Albanian procedural law, is equivalent to any other final judgment, while according to B IA it is equivalent to an authentic instrument (Article 59 of B IA: "A court settlement which is enforceable in the Member State of origin shall be enforced in the other Member States under the same conditions as authentic instruments.").

According to the Albanian procedural law, judgments declining jurisdiction by virtue of a jurisdiction clause are non-final judgments and are not considered enforcement titles. Therefore, this is problematic in light of the euro-autonomous definition, given that according to the euro definition, that judgment becomes res judicata and is enforceable. ${ }^{5}$

\subsubsection{Res judicata effect of judgments versus enforcement}

According to the Albanian legal order, any judgment that has become res judicata is always enforceable, but not vice versa, because not every judgment that is enforceable is considered res judicata. ${ }^{6}$ For example, Article 317 ACPC provides for the judgment on temporary enforcement that does not have res judicata effect but is enforceable. Moreover, the judgments on security measures do not have (and cannot have) the res judicata effect, but they are enforceable at the moment the court issues them. Also, the judgment on fines imposed by the court, judgment on the mandatory taking of evidence, the judgment on the part ordering court costs are enforceable but do not have res judicata effect.

\footnotetext{
${ }^{5}$ Case C-456/11, Gothaer Allgemeine Versicherung and others, ECLI:EU:C:2012:719.

${ }^{6}$ Unifying Judgment of the Joint Chambers of the High Court, No. 2, dated 03.11.2014, para. 31.
} 
The ACPC identifies the final judgment of the Appellate Court with the judgment of res judicata effect (Articles 450, 450/a and 472 ACPC). These provisions have generated debates and issues that have been addressed not only by the domestic doctrine (Kola Tafaj, Vokshi, 2018: p. 308) but also by the ECHR's judgments in which the RoA has been one of the parties. ${ }^{7}$

According to Article 450 ACPC, the judgment of the first instance becomes irreversible when: a) it cannot be appealed; b) no appeal (at the Appellate Court) has been made against it within the time limits determined by law or when the appeal has been withdrawn; c) the appeal submitted has not been accepted; d) the judgment (of the first instance) is upheld, is changed, or the case is dismissed in the court of the second instance (appeal court). A judgment that becomes irreversible shall be mandatory for the parties, their heirs, for the people who deprive the parties of their rights, the court that has issued the judgment, and for all other courts and other institutions. A judgment that has become irreversible has authority only over what has been decided between the same parties, on the same subject (petitium), and for the same cause (causam petendi). A conflict that has been resolved with an irreversible judgment cannot be adjudicated again unless the law provides otherwise (Article 450/a ACPC). A civil irreversible condemnatory judgment is an enforcement title, and therefore binding (Article 510/a ACPC).

Meanwhile, against the judgment of the Appellate Court (which, as explained above, is considered an irreversible judgment), parties are free to exercise the right of appeal (recourse), which is an ordinary means of appeal. ${ }^{8}$ Judgments of the Appellate Court and those of the first instance may be appealed through recourse to the High Court: a) for incorrect implementation of the substantive or procedural law of essential importance for the unification, certainty and/or development of the case law; b) when the appealed judgment is different from the case law consolidated by the Civil Chamber or the unifying case law of the Joint Chambers of the High Court; c) there are serious violations of procedural norms, resulting in the invalidity of the judgment or the hearing procedure. (Article 472 ACPC).

\footnotetext{
${ }^{7}$ ECtHR 25 September 2012, Case No. 58555/10, Rrapo v Albania, para. 80-85; ECtHR 29 September 2009, Case No. 32907/07, Gjyli v Albania para. 33-34; ECtHR 24 June 2014, Case No.1542/13 Becaj v Albania para. 32-33; etc. 8 Judgment of Constitutional Court No. 6/2003.
} 
Beyond the above provisions, the Albanian doctrine and case law share another view concerning the res judicata effect of the judgment. The Albanian legal doctrine has held that the judgment of the Appellate Court, despite being considered irreversible and enforceable under Articles 450 and 510 ACPC, becomes res judicata only after the High Court rejects the recourse or adjudicates the recourse and upholds the judgment of the Appellate Court or the judgment of the first instance court. In other words, the judgment of the High Court (and not the judgment of the Appellate Court) should have the effect of resjudicata as long as the judgment of the Appellate Court may be appealed by an ordinary means of appeal (Kola Tafaj, Vokshi, 2018: p. 308).

Moreover, according to the Joint Chambers of the Albanian High Court (regardless of the fact that it refers to a criminal case, the issue is the same), a judgment can be enforced without necessarily having the status of res judicata. The judgment of the Appeal Court is enforceable but does not constitute a res judicata judgment. In other words, every judgment that is res judicata is always enforceable, but not the other way around, since not every enforceable judgment is res judicata. ${ }^{9}$

The confusion in the Albanian legislation (identification of the final judgment with the res judicata judgment) has been addressed directly in some judgments of the European Court of Human Rights (hereinafter: ECtHR) in which one of the parties has been the RoA. In the case Rrapo vs. the Republic of Albania, ${ }^{10}$ the ECtHR states that the Court does not accept the Government's argument that, in extraditing the applicant, they complied with the final Appellate Court's judgment. For the purposes of the Convention, a final judgment which has become res judicata is a judgment which may not be subject to control by a higher instance court and, eventually, quashed, whereas the present Court of Appeal's judgment was lawfully quashed by the Supreme Court's judgment and those proceedings are still pending. ${ }^{11}$ The ECtHR has held the same position in other cases such as Gjyli vs. the Republic of Albania, Xheraj vs. the Republic of Albania, etc.

\footnotetext{
${ }^{9}$ Unifying Judgment of the High Court No. 2 dated on 03.11.2014, para. 31.

${ }^{10}$ ECtHR 25 September 2012, Case No. 58555/10, Rrapo v Albania.

11 ECtHR 25 September 2012, Case No. 58555/10, Rrapo v Albania, para. 80-85; ECtHR 29 September 2009, Case No. 32907/07, Gjyli v Albania para. 33-34; ECtHR 24 June 2014, Case No.1542/13 Becaj v Albania para. 32-33; etc.
} 


\subsection{Irreversible/peremptory criminal judgments in the part dealing with property rights}

The Albanian Code of Criminal Procedure (hereinafter: ACCP) (Article 61-68) provides for the concept of civil action in criminal proceedings. Under Article 61 ACCP, a person who has suffered damage from the criminal offense or his or her heirs may bring a civil action in criminal proceedings against the defendant or civil defendant to seek restitution and compensation of damage. The final judgment of the criminal court may accept in whole or in part the civil action or dismiss it if finds it unfounded in law or evidence. In the first case, the court will decide regarding certain property or non-property rights (assessable in monetary value). This means that when the final criminal judgment becomes irreversible, it will be subject to enforcement (for the part of the obligations imposed on it), same as civil court judgments (Article 510/b ACPC).

\subsection{Foreign judgments that are recognized in the RoA}

Under the Code of Civil Procedure, a foreign judgment can be enforced in Albania only after it is recognized by an Appellate Court, ${ }^{12}$ which does not decide on the merits of the case ${ }^{13}$ but only reviews if there are any grounds for the refusal of recognition. The recognition and enforcement of foreign judgments in Albania are regulated under the Code of Civil Procedure (Articles 393 to 398), which provides that in the absence of bilateral or multilateral agreements on the recognition and enforcement of foreign judgments, the provisions of the Code of Civil Procedure shall apply. Unlike some states, such as Turkey (Ceyda Sural Efecinar, 2019: p. 29) or Austria (Feichtinger, Lehnercerha, 2006: p. 200), the Albanian legislation does not provide for reciprocity as a condition for granting recognition to a foreign judgment.

Since Albania is not yet an EU Member State, the B IA does not apply to the recognition and enforcement of civil or commercial judgments. Albania has not ratified the Convention on Choice of Court Agreements (30th June 2005), which is applicable for the recognition and enforcement of a judgment given by a court of a

\footnotetext{
12 See Article 395 of Albanian Code of Civil Procedure.

${ }^{13}$ See Article 397 of Albanian Code of Civil Procedure.
} 
Contracting State designated in an exclusive choice of court agreement (Article 8). On 8th April 2010, Albania ratified (along with four other countries) the Hague Convention on the Recognition and enforcement of foreign judgments in civil and commercial judgments, concluded on 1st February 1971. Article 21 of this Convention ${ }^{14}$ requires the conclusion of a Supplementary Agreement between the contracting States in order to make the Convention applicable. Albania has not concluded any Supplementary Agreement for that purpose. Therefore, the Convention is not applicable. The author remains very optimistic that Albania will ratify the New Hague Convention on the Recognition and enforcement of foreign judgments in civil and commercial judgments, Judgment Convention of $2^{\text {nd }}$ July 2019, among many other countries.

With regard to the recognition and enforcement of civil and commercial judgments, Albania has signed the following eight bilateral agreements:

1. Agreement between the Republic of Albania and the Republic of Bulgaria on Mutual Legal Assistance in Civil Matters, ratified by Law No. 9348, dated 24.02.2005,

2. Agreement between the Government of Albania and the Government of North Macedonia on Legal Assistance in the field of Civil and Criminal Matters, signed on 15.01.1998,

3. Convention on Mutual Assistance in Civil, Commercial and Criminal Matters between the Republic of Albania and the Republic of Turkey, signed on 15.03.1995,

4. Protocol on the Exchange of Instruments of Ratification of the Convention on Mutual Assistance in Civil, Commercial and Criminal Matters between the Republic of Albania and the Republic of Turkey, signed and in force on 20.02.1998,

5. Convention between the Republic of Albania and the Republic of Greece on Judicial Assistance in Civil and Criminal Matters, signed on 17.5.1993,

6. The Russian Federation "On Legal Aid in Civil, Criminal and Family Matters” ratified by law No. 8061, dated 08.02.1996, FZ No. 2/1996, p. 35,

\footnotetext{
14 "Decisions rendered in a Contracting State shall not be recognized or enforced in another Contracting State in accordance with the provisions of the preceding Articles unless the two States, being Parties to this Convention, have concluded a Supplementary Agreement to this effect."
} 
7. Romania "On Mutual Legal Assistance in Criminal and Family Civil Matters," Decree No. 3250, dated 17.04.1961, GZ No. 6/1962, p. 125,

8. Hungary "On Mutual Legal Assistance in Civil, Criminal and Family Matters,” Decree No. 3119, dated 06.06.1960, GZ No. 3/1961, p. 75.

As a matter of fact, the above-listed bilateral agreements are obsolete, written in a very poor language, and in some cases incomprehensible and therefore almost ineffective. Out of around 50 judgments of the Appellate Courts of Tirana and Durres, only 3 or 4 of them have addressed these Agreements without taking into consideration their provisions.

Recognition of a foreign judgment on issues regarding property in rem, or registration of trademarks, patents, etc., which fall under the exclusive jurisdiction of the Albanian courts, will be refused, because according to Article 394 (a), "the judgment of a court of a foreign state does not become effective in Albania when in conformity with the provisions in effect in the RoA, the dispute cannot be within the competence (jurisdiction) of the court which has issued the judgment." Also, when judgments involve concepts that are unknown to the Albanian legal system, they risk not being recognized by the Albanian courts because under Article 394(dh) ACPC, the judgment of a court of a foreign state does not become effective in Albania when it does not comply with the basic principles of the Albanian legislation. For example, the Appellate Court of Tirana has refused to recognize a default judgment issued by a North Macedonian court, reasoning that this judgment does not comply with the basic principles of the Albanian legislation because the Albanian legislation does not provide for the default judgment. ${ }^{15}$

\subsubsection{Expansion of the res judicata effect to a foreign judgment after its recognition}

The Albanian legal order and doctrine do not address this issue explicitly, and the legal practice does not offer cases either. Any foreign judgment shall be enforceable in Albania after being recognized there. Once the foreign judgment is recognized in the RoA, then the Albanian court, upon request of the party, must take into consideration its res judicata effect. A foreign judgment cannot be recognized in

\footnotetext{
${ }^{15}$ Judgment of District Court of Tirana No. 7, dated 28.01.2019.
} 
Albania if it is irreconcilable with an earlier judgment issued by an Albanian court involving the same causa petendi, the same petitium, and between the same parties. (Article 394(c) ACPC) This provision guarantees the aim of the Albanian legislation to avoid different rulings on the same issue.

In every system, the res judicata effect covers the operative part of the judgment. However, the same does not apply to the reasoning of the judgments. According to some foreign legislation, the res judicata effect of the judgment covers only the operative part of the judgment (e.g., Germany, Switzerland, etc.), and according to some others, the effect covers even the reasoning (e.g., Italy, etc.). Under the jurisprudence of the Albanian Constitutional Court, res judicata includes not only the operative part of the judgment but also the findings of fact and the application of the law set out in the reasoning of the decision, under the condition that the fact and legal relationships are performed in function of rendering the decision and form the object of the adjudication upon which the court rendered the judgment. ${ }^{16}$

In this regard, the question might be: Will the Albanian courts recognize the res judicata effect of the reasoning of a foreign judgment issued in a country the legislation of which does not recognize that effect for its judgments?

The majority of the Albanian judges and lawyers are more inclined to support the view that once the foreign judgment is recognized in Albania, the effect of that judgment should be equal to that of the other Albanian judgments. Following this opinion and having regard to the position of the Albanian courts concerning the res judicata effect of the reasoning of the judgment, it can be concluded that the Albanian courts will be bound even by the reasoning of the foreign judgment, even though according to the legal order of the state of origin the resjudicata effect does not cover the reasoning of the judgment.

\footnotetext{
${ }^{16}$ Judgment of the Constitutional Court No. 24/08; Judgment of the Constitutional Court No. 14/17; Judgment of the Constitutional Court No. 36/13; Judgment of the Constitutional Court No. 41/16; Judgment of the Constitutional Court No. 87/16; Judgment of the Constitutional Court No. 71/17; Judgment of the Constitutional Court No. 62/15; Judgment of the Constitutional Court No. 44/14; Judgment of the Constitutional Court No. 36/10; Judgment of the Constitutional Court No. 21/10.
} 
There is another theory (including the author's opinion) that a foreign judgment cannot be given more "power" than it has in its country of origin. Therefore, the interested party may raise the issue that the reasoning of the judgment does not have the res judicata effect according to the law of the state of origin of the judgment. In case of a judgment issued by a state court that does not give the res judicata effect to the reasoning of the judgment (e.g., Switzerland), the Albanian courts should not consider the findings in the reasoning of that judgment. In this latter case, the Albanian courts will be bound by what is stated in the operative part (res judicata effect) and will not take into consideration what is stated in the reasoning of the foreign judgment.

\subsection{Foreign arbitral awards that are recognized in the RoA}

Pursuant to Article 399 ACPC, Articles 393-398 ACPC, which regulate the recognition of foreign court's judgments, are applicable mutadis mutandis to the recognition of foreign arbitral awards. In addition, the RoA has ratified several international agreements for the recognition of foreign arbitral awards, the most important of which is the Convention "On the Recognition and Enforcement of Foreign Arbitral Awards" of the 7th June 1959, otherwise known as the New York Convention. Other agreements which provide for the recognition of an international arbitral award are (i) Agreement on mutual judicial assistance in the civil area between the Republic of Albania and the Hellenic Republic, ratified by Law No. 7760, dated 14.10.1999; (ii) Agreement on mutual judicial assistance in the civil area between the Republic of Albania and the Republic of Turkey ratified by Law No. 7760, dated 14.10.1999.

The above bilateral agreements were concluded by the RoA before the ratification of the New York Convention and, with the ratification by the RoA of the latter, have become almost ineffective because their provisions are similar provisions to those of the New York Convention. The New York Convention remains the most important legal act for the recognition and enforcement of international arbitral awards. However, since Article VII/ (1)(2) of the New York Convention ("the most favorable provision") allows for reference to national law, the provisions of the ACPC (Article 393-398) are widely applied in legal practice. 


\subsection{Arbitral awards issued in the RoA}

An arbitral award issued in the RoA is considered an irreversible judgment at the moment of its proclamation unless any of the grounds provided in Article 434 ACPC ${ }^{17}$ exists. The procedure of enforcement of a domestic arbitral award is the same as that of judgments of the Albanian state courts. The only difference is that in the case of a judgment, the Enforcement Order is issued as an integral part of the final judgment, whereas in the case of a domestic arbitral award, the party interested in the enforcement of the award must submit a request for issuing an Enforcement Order at the court of the place where the award is intended to be enforced. Then, the award will be enforced by the Enforcement Officer according to the rules set out in the Code of Civil Procedure for any other Albanian judgment.

\subsection{Notarial deeds containing monetary obligations}

A notarial deed as an enforcement title must itself constitute a legal action with a one-sided obligation to pay a certain sum of money. Furthermore, the enforceable obligation contained therein cannot be contested for its non-existence at the time of drafting and signing the act, nor is there a need to prove it. It is presumed true. The act of payment of a sum of money, drawn up in the form of a notarial declaration, being an enforcement title, may be challenged only on the grounds of falsehood or on the grounds provided for in section 609/1 ACPC (invalidity of the enforcement title).

The notarial deed of paying a sum of money as an enforcement title resembles a bill of exchange in its content but differs from it because it does not have the quality of a valuable letter and, therefore, it cannot be used marketed as such. A notarial deed as an enforcement title may also contain an obligation arising from a previous contract or, more broadly, from any other prior legal action to which the debtor has

\footnotetext{
17 Article 434 ACPC: "Although the parties to the agreement have provided for the withdrawal of the appeal, the arbitral award may be appealed to the Appellate Court only when:

a) the arbitral tribunal has been formed irregularly;

b) the arbitral tribunal has unjustifiably declared its jurisdiction or incompetence to adjudicate the dispute;

c) the arbitral tribunal in its decision has exceeded the claims for which it has been invested or has not ruled on one of the main claims of the lawsuit;

d) the equality of the parties and their right to be heard in a procedure based on the principle of adversarial proceedings has not been respected;

e) the award is contrary to public order in the RoA."
} 
been a party. This new obligation, which often does not extinguish previous liabilities, as it is assumed by the debtor unilaterally and unconditionally, gains an independent existence. Documents for granting bank loans or documents for granting loans from non-banking financial institutions should be notarized to be considered enforcement titles. Then, the same procedure for the enforcement of notarial deeds applies.

A notarial deed is not an enforcement title per se. The Albanian courts are the competent authority to declare if such an act can be an enforcement title through issuing an Enforcement order.

Usually, the notarial deeds capable of being enforceable contain the expression that: "The parties declare that they agree, recognize and acknowledge that this notarial statement constitutes an enforcement title." However, this citation does not make a notarial deed an enforcement title. It is the court that assesses the capacity of the notarial deed to become an enforcement title and issue an enforcement order.

With regard to the criteria that the court evaluates when deciding on whether or not a notarial deed is an enforcement title, one should refer to the Unifying Judgment of the Joint Chambers of the High Court No. 980, of 29.9.2000, which aims to clarify (i) what is meant by notarial deeds containing monetary obligations in terms of the enforcement title; (ii) comparison of these deeds with the bills of exchange, as the most striking one to highlight their nature and features. According to the said Unifying Judgment, "a two-pronged legal action (contract), whether a bilateral contract, such as a sale contract or a one-sided contract, such as a loan contract, cannot be an enforcement title. For an act issued by a competent state body, or prepared and certified by a public servant, under the conditions explicitly provided for by law, to be an enforcement title, it must contain a recognized, precisely defined, and a payable obligation, which is not related to meeting certain deadlines and above all, is unconditional from other circumstances or from other mutual obligations." However, in the judicial practice, this is still a grey area, which leads to inconsistent application of the law, particularly in the areas of enforcement of contracts and enforceable deeds. (“Study Report” 2019: p. 23, para. 4) 


\subsection{Bills of exchange, cheques and order papers equivalent to them}

With regard to the meaning of the terminology "cheque," "Bills of exchange," etc. their meaning in the special law should be taken into consideration, e.g., Law No. 8077, of 22.2.1996 "On bills of exchange and pledges"; Decree No. 3702, of 8.7.1963 "On the cheque" as amended by Law No. 7782", of 26.1.1994, etc.

\section{$1.8 \quad$ Other documents}

The last paragraph (e) of Article 510 ACPC defines as enforcement titles other documents that are considered as such under special laws and the enforcement officer is authorized to enforce them. This provision covers all those cases where special law explicitly provides the documents that should be considered enforcement titles. Examples:

1. Law No. 7703, dated 11.5.1993 "On Social Security in the Republic of Albania" (Article 15 (4)) provides that "The Act, which contains the obligation to pay contributions, constitutes an enforcement title and is enforced by the Enforcement officer." Also, Article 18(2) of this law states that: "For unpaid contributions by entities within the deadline, the social security authorities have the right to issue an obligation order, which is an enforcement title and is enforced by the Enforcement officer."

2. Law No. 8662, dated 18.09.2000 "On the treatment as an enforcement title of the electricity consumption bill" (Article 1), expressly states that: "The tax bill on electricity consumption, sale, purchase and the bill of electricity transmission and distribution service, according to the model set by the Ministry of Finance, pursuant to Article 36 of the Law No. 7928, dated 27.4.1995 "On Value Added Tax," is an enforcement title and the Enforcement officer is charged with its enforcement."

3. Law No. 8975, dated 21.11.2002 "On the Treatment of Drinking Water Tax Bills as an Enforcement Title" (Article 1), stipulates that the Bill on Consumption of Drinking Water, according to the model set by the Ministry of Finance, pursuant to Article 36 of the Law No. 7928, dated 27.4.1995 "On Value Added Tax," is an enforcement title and the Enforcement officer is responsible for its enforcement." 
4. Law No. 48/2014 "On Delayed Payments in Contractual and Commercial Obligations" (Article 16) provides that: "1. Monetary obligations arising from commercial legal transactions that have not been paid within the relevant payment deadline, under this Act, except as provided in Article 485 of the Civil Code, constitute an enforcement title and are enforced by the Enforcement officer, regardless of the value, when: a) the creditor has delivered the goods or provided the services under the contract and the law; and b) the debtor has not objected the obligation. 2. In such cases, the obligation together with interests on arrears and the reimbursement of expenses for the repayment of the areas may be enforced in accordance with the provisions of the Code of Civil Procedure."

5. Law No. 10385, dated 24.02.2011 “On mediation for solving the disputes" (Article 23(3)) provides that the mediation agreement made in accordance with Article 22 of the said law is an enforcement title; etc.

\section{$2 \quad$ Enforcement Process}

\subsection{Enforcement Order}

The enforcement acts provided in Article 510 of the ACPC are not "enforcement titles" per se. To be considered as such, they should be declared through a judgment named Enforcement Order. Enforcement Order (Urdhër ekzekutimi) is a court judgment that establishes the existence of an enforcement title capable of being enforced and consequently orders the enforcement authority to enforce the content of that enforcement title. The Albanian law does not explicitly provide for a statute of limitations for enforcement of a judgment, which is an enforcement title. However, referring to Article 113 of the Albanian Civil Code, indirectly, it is understood that the enforcement of judgments is time-barred depending on the type of lawsuit for which they have been granted. When the judgment concerns a lawsuit to which the statute of limitation does not apply, its mandatory enforcement is also not time-barred (Article 113(2) CC). 
An enforcement process cannot commence without having an Enforcement Order. Exceptionally, interim judgments on security measures and on fines imposed by the court, and judgments on the mandatory taking of evidence, judgments on the part that order court's costs, as well as the civil judgments of the court given on temporary enforcement, are directly enforced by the bailiff's office, after the notification of the judgments. In the cases where the enforcement title is a judgment issued by the Albanian court (including the judgment of the Appeal Court for recognition of a foreign judgment or arbitral award), the Enforcement Order is issued by the court that issues the judgment, by noting in the enacting clause of this judgment that "the judgment is enforceable by the Bailiff Officer" (Article 310 (III) $(1 / 1)$ ACPC). If the judgment that contains this phrase becomes irreversible, the interested party may submit a request to the Enforcement Officer to enforce the judgment. A judgment that does not contain this phrase (which is called Enforcement Order) cannot be enforceable (Article 310 and 511 ACPC).

In all other cases, the interested party, who intends to enforce an enforcement title (notarial deed, bill of exchange, domestic arbitral award, etc.) should address to the court of the first instance of the place where the enforcement will take place a request to issue an Enforcement Order. The examination of the case to issue an Enforcement Order is conducted by the judge ex parte. The court issues the Enforcement Order based on the documents submitted by the applicant. The Enforcement Order contains:

a) identifying data of the debtor and creditor;

b) the origin of the obligation;

c) the concrete obligation deriving from the enforcement title until the moment of issuance of the enforcement order;

d) when the enforcement title, for which an enforcement order is issued, is an act for granting bank credit or monetary obligations, the Court shall provide for the legal interest rates in accordance with the legislation in force that regulates late payments in contractual and commercial obligations (Article 511 ACPC).

Against a judgment refusing to issue an Enforcement Order, an appeal may be lodged in accordance with the rules on special appeals. If it is argued otherwise (argumentum ad contrario), no appeal can be made against the judgment of the court that accepts the request for the issuance of the enforcement order. If a person will 
be affected by the enforcement of an enforcement title, then he or she has the opportunity to use the means of defense provided by Articles 609, 610, 612 ACPC.

\section{$2.2 \quad$ Voluntary and mandatory enforcement}

The Albanian judgments do not contain any time period within which the obligation should be fulfilled voluntarily by the debtor or a period of time within which the judgment should not be enforced. The issuance of an Enforcement Order does not mean the beginning of the mandatory enforcement process but is a precursor. The judgment enforcement procedure follows two stages: (1) voluntary enforcement and (2) mandatory enforcement. The Enforcement Officer should exhaust the voluntary enforcement before proceeding with mandatory enforcement.

The notice of voluntary enforcement is provided explicitly by Articles 517-519 ACPC. At the commencement of the enforcement of a judgment, the Enforcement officer issues to the debtor a notice for voluntary enforcement of the obligation contained within the Enforcement Order designating for this purpose a timeframe of: (i) five days when the judgment involves a salary or an order for maintenance and (ii) ten days for all other judgments. After receiving the notice for voluntary enforcement, the debtor is obliged to declare in writing his or her property status as well as the objects or credit that third persons owe to him or her if he or she is requested to do so by the Enforcement officer. In special cases, upon a request of the debtor, the court of the first instance, taking into consideration the financial situation of the debtor or other circumstances of the case, and after hearing the creditor, may postpone the time limit of enforcement of the monetary obligation or may divide such an obligation in installments, except when this obligation arises from a bank loan. (Article 517 ACPC)

The notice of voluntary enforcement must contain a summary of the enforcement order, the creditor's place and address, and the warning made to the debtor that the mandatory enforcement shall start if the enforcement will not be performed voluntarily by him or her within the time limit defined in the notice. (Article 518 ACPC) 
The mandatory enforcement cannot start before the time limits provided in Article 517 of the ACPC above (time frame for voluntary enforcement) have expired unless there is a danger that the enforcement shall become impossible with the expiry of the time limit. In such a case, the Enforcement officer can start immediately with the mandatory enforcement (Article 519 ACPC).

\subsection{Conditions for suspension of the enforcement process}

According to Article 615 ACPC, the enforcement is suspended: a) by a judgment as provided by law; b) on the request of the creditor; c) one of the parties dies or has terminated as a legal person; one of the parties does not have or has later lost the legal capacity to act as a party, and it is considered necessary to appoint to a legal representative; with the exception of the sale by auction of an immovable thing, on which the announcement is made; d) in other cases provided by law; e) when the Enforcement Officer, alone or under the auspices of the creditor, does not find the property of the debtor within six months from the commencement of enforcement; f) when the creditor does not appear without reasonable grounds, within three months from the second notice by letter, made by the Enforcement Officer.

When the enforcement title is an act providing bank loans or an act providing loans from non-banking financial institutions, the court may decide to suspend the enforcement only with a guarantee and for a period not longer than three months, except when the court, within this term, takes a final judgment to accept the claim. When the three-month term expires or when the court, within this term, decides to refuse the claim or dismiss its adjudication, the measure to suspend the enforcement of the judgment is considered not in force. Suspension of the judgment is not decided by the court when the debtor claims that the obligation imposed with the enforcement title, which is an act for granting bank loans or an act for granting loans from non-banking financial institutions, exists to a lesser extent. The court examines the requests for suspension within five days. A special appeal may be made against this judgment. The court of appeal shall examine the appeal within 30 days from the date of its filing in this court (Article 609 ACPC). 
Appeal against Enforcement Officer's actions or refusal to act shall not suspend enforcement of the judgment unless the court decides otherwise. When the enforcement title is an act for granting bank loans or an act for granting loans from non-banking financial institutions, and the court has decided to suspend the enforcement of the judgment, the effect of suspension measure is considered to have ceased within 20 days from the moment of the grant of the judgment on suspension (Article 610 para. 3 and 4 ACPC).

Each third person who claims to be the owner of the object on which enforcement is made may bring an action to exercise his or her right and, if that is the case, to exempt the object from seizure and sale. In these cases, the court may decide on a temporary measure of the suspension of the enforcement with or without guarantee (Article 612 para. 2 ACPC).

Following the dismissal of the suspension measure, enforcement continues from the last procedural action at the moment of suspension.

\subsection{Expenses of the enforcement process}

The fixed fees set for enforcement of the Enforcement Order are initially paid by the creditor and, upon completion of the enforcement procedure, are charged to the debtor. Other expenses during the enforcement process are paid by the party that caused them. The rate of the success fee, with the exception of cases when that is not applicable, is determined by agreement between the creditor and the bailiff officer, in accordance with the legislation governing the bailiff service (Article 525 ACPC).

\subsection{Enforcement against the successor}

A judgment that has become irreversible is mandatory for the successors of the parties (Article 451/a ACPC). When a succession of the parties, either of the creditor or the debtor, occurs after the rendering of the judgment, during enforcement proceedings, enforcement will be suspended, with the exception of the sale by auction of an immovable thing, on which the announcement is made. ${ }^{18}$ In this case, the suspension continues until the person who possesses the rights or the legal

\footnotetext{
18 Article 615 and 297 of the ACPC.
} 
representative of the party which has lost the legal capacity to act as a party appears to participate in the case. The suspension of the enforcement, except in the cases when it is decided by the court, is decided by the Enforcement Officer. The interested persons must show the Enforcement Officer a certificate of inheritance, which is issued by notaries, before the enforcement continues on behalf or against the successors. The Enforcement Order against the debtor who leaves inheritance is executed on the property of his or her heirs but within the amount of the property inherited by them from the debtor leaving the inheritance (Article 520 ACPC).

However, not all kinds of judgments are mandatory for the successors of the parties. The judgments on non-pecuniary damages are related to the personal character and therefore are not hereditary. Another example, according to Article 212 of the Albanian Family Code, is the obligation for alimony ceases with the death of the obligated person and of the person who benefits that, even if this obligation, which is contained in an irreversible judgment, has not been enforced.

\section{$3 \quad$ Means of challenges of the enforcement titles}

During the enforcement stage, the interested party may exercise three types of actions: 1. Claim for the invalidity of the enforcement title (Article 609 ACPC); 2. Appeal against the actions of the Enforcement Officer (Article 610 ACPC); 3. Third Person's Claim for the revendication of the object (Article 612 ACPC).

An enforcement title may be changed during the enforcement process. The debtor may request before the competent court of the place of enforcement to declare that the enforcement title is invalid or that the obligation does not exist or that it exists to a smaller amount or is extinguished subsequently. The time limit for lodging this action is 30 days from receipt of the notification on the commencement of the mandatory enforcement. When the enforcement title is a judgment or an arbitral award, the debtor may contest the enforcement of the title only for facts that occurred after the issuance of those judgments (Article 609 ACPC).

Against the actions of the Enforcement Officer, carried out against of the procedures provided by the ACPC, and against the refusal of the Enforcement Officer to carry out an action imposed by law, the parties may submit an appeal to the court that executes the judgment within five days from the day of performance 
of the action or refusal, when the parties have been present in the conduct of the action or have been summoned and, in other instances, from the day they have been notified or have been informed of the action or refusal. Against the actions of judicial bailiffs who exercise the public activity of judicial enforcement service organized on a private basis, the debtor may lodge a complaint with the court where the executive title is enforced within five days from the performance of the action (Article 610 ACPC).

Moreover, during the enforcement stage, each third person who claims to be the owner of the object against which enforcement is addressed may bring an action to exercise his or her right and, if that is the case, to exempt the object from seizure and sale. The action should be brought against the creditor and the debtor in the court of the place of the enforcement of the judgment. In these cases, the court may decide as a temporary measure the suspension of the enforcement with or without guarantee (Article 612 ACPC).

\section{$4 \quad$ Some remarks regarding enforcement in Albania}

- The Albanian legal order does not enable the enforcement of interim measures issued outside the territory of the RoA. ${ }^{19}$ Exceptionally, the bilateral agreement between the Republic of Albania and the Republic of Bulgaria on Mutual Legal Assistance in Civil Matters (Article 19), ratified by Law No. 9348, of 24.02.2005, provides that: " 1 . In accordance with this Agreement, the Contracting Parties recognize and enforce in their territory the court judgments that have been issued and are recognized in the territory of the other Contracting Party. 2. The term "judicial judgments" for both Parties means a final or interim judicial judgment and a criminal judgment relating to a civil claim,"

- The Albanian legal order does not allow the enforcement of settlement agreements that may constitute an enforcement title according to foreign legislation.

\footnotetext{
${ }^{19}$ Judgment of the Appellate Court of Tirana No. 32/1010, dated 01.03.2012.
} 
- The Albanian legal order does not allow the enforcement of the European Payment Order or other forms of acts enforceable under foreign legislation except when they are irreversible judgments.

Exceptionally, the Appellate Court of Tirana ${ }^{20}$ has recently interpreted that a European Payment Order issued by an Italian court is equal in terms of effects with a final court decision. In this way, the court has expanded the interpretation of the legal provisions in force, including the European Payment Order. In this judgment, the Court reasoned as follows: “... The Court of Bergamo Italy has issued the Payment Order No. 11468/2015-RG, No. 5744/2015, of 24.11.2015, according to which the Ministry of Tourism, Culture, Youth and Sports of Albania is obliged to pay in favor of the requesting party the amount of 11,010.00 Euros, interests on arrears, as well as legal costs for this Payment Order ..... The Appellate Court assesses that it does not result that this judgment of the foreign court in the concrete case does not comply with the basic principles of the Albanian legislation or that there is any other obstacle from those provided in Article 394 ACPC. It is true that the CPC of the RoA does not recognize the procedure for issuing a Payment Order, as is the case in many EU countries and as it is foreseen to be included in our Code, as a measure for effective adjudication, but the judgment that resulted at the end of this procedure has the character of a court judgment on the obligation of the debtor party to make the payment, as a fulfillment of the contractual obligation."

- Under the Albanian procedural law, a court settlement is equivalent to any other final judgment, while according to B IA, it is equivalent to an authentic instrument. (Article 59 of B IA "A court settlement which is enforceable in the Member State of origin shall be enforced in the other Member States under the same conditions as authentic instruments.").

- According to the Albanian procedural law, judgments declining jurisdiction by virtue of a jurisdiction clause are non-final judgments and are not considered enforcement titles. Therefore, this is problematic in the light of the euroautonomous definition of the judgment, given that according to it, the judgment becomes res judicata and is enforceable. ${ }^{21}$

\footnotetext{
${ }^{20}$ Judgment of the Appellate Court of Tirana No. 40, dated 23.02.2017.

${ }^{21}$ Case C-456/11, Gothaer Allgemeine Versicherung and others, ECLI:EU:C:2012:719.
} 


\section{$5 \quad$ Conclusions}

The range of foreign enforcement titles that can be recognized and enforced in Albania is narrower than that provided in the EU countries. Therefore, it should be expanded to include, in addition to irreversible judgments, other European enforcement acts, such as European Payment Order, Settlement Agreements, Authentic instruments, etc.

\section{References}

Albanian Civil Procedure Code (1996) as amended most recently in 2017.

Albanian Code of Criminal Procedure.

Law No. 10 385, "For mediation on solving the disputes," amended lately by Law No. 26/2018, dated 24.2.2011.

Bilateral agreement between the Republic of Albania and the Republic of Bulgaria on Mutual Legal Assistance in Civil Matters ratified by Law No. 9348, dated 24.02.2005.

Agreement between the Government of Albania and the Government of North Macedonia on Legal Assistance in the field of Civil and Criminal Matters, signed on 15.01.1998.

Convention on Mutual Assistance in Civil, Commercial and Criminal Matters between the Republic of Albania and the Republic of Turkey, signed on 15.03.1995.

Protocol on the Exchange of Instruments of Ratification of the Convention on Mutual Assistance in Civil, Commercial and Criminal Matters between the Republic of Albania and the Republic of Turkey, signed and in force on 20.02.1998.

Convention between the Republic of Albania and the Republic of Greece on Judicial Assistance in Civil and Criminal Matters, signed on 17.5.1993.

Agreement between and The Russian Federation "On Legal Aid in Civil, Criminal and Family Matters" ratified by law No. 8061, dated 08.02.1996, FZ No. 2/1996, p. 35.

Agreement between Albania and Romania "On Mutual Legal Assistance in Criminal and Family Civil Matters” Decree No. 3250, dated 17.04.1961, GZ No. 6/1962, p. 125.

Agreement between Albania and Hungary "On Mutual Legal Assistance in Civil, Criminal and Family Matters” Decree No. 3119, dated 06.06.1960, GZ No. 3/1961, p. 75.

Regulation (EU) No. 1215/2012 of the European Parliament and of the Council of 12th December 2012 on jurisdiction and the recognition and enforcement of judgments in civil and commercial matters, OJ L 351, 20.12.2012.

Feichtinger J., Lehner K. (2006) Comparative Study of 'Residual Jurisdiction' in Civil and Commercial Disputes in the EU (National Reporter: Vienna). Retrieved from

http://ec.europa.eu/civiljustice/news/docs/study_resid_jurisd_austria_en.pdf

Kola Tafaj F., Vokshi A. (2018) Procedure Civile, Pjesa II (Tirana: Albas).

Sural Efecinar C. (2019) The benefit of Albania by Multilateralism of Convention on the Recognition and Enforcement of Foreign Judgments in Civil and Commercial Matters ("Judgments Convention"). Proceedings of the $16^{\text {th }}$ Annual Regional PIL Conference on Matrimonial and Registered Partnership Property Regimes in EU Private International Law/ HCCH Judgments Convention (pp. 3558) (Tirana: Onufri).

Magnus U., Mankowski P. (2016) European Commentaries on Private International Law, Commentary. Vo1.1 (Cologne: Selp, Verlag dr. Otto Schmidt KG).

Stone P. (2018) Stone on Private International Law in the European Union, Fourth Edition (Northampton: Edward Elgar Publishing Limited). 
Study Report on the Legal Framework for the Enforcement of Commercial Creditors' Claims in Selected European Bank for Reconstruction and Development Countries of Operations (Albania, Croatia, Cyprus, Greece And Ukraine).

(2019, March). Retrieved from https://www.ebrd.com/documents/ogc/enforcement-studyreport.pdfgulfnews.com

Judgment of the Constitutional Court No. 71/17.

Judgment of the Constitutional Court No. 14/17.

Judgment of the Constitutional Court No. 41/16.

Judgment of the Constitutional Court No. 87/16.

Judgment of the Constitutional Court No. 62/15.

Judgment of the Constitutional Court No. 44/14.

Judgment of the Constitutional Court No. 36/13.

Judgment of the Constitutional Court No. 36/10.

Judgment of the Constitutional Court No. 21/10.

Judgment of the Constitutional Court No. 24/08.

Judgment of the Constitutional Court No. 6/2003.

Unifying Judgment of the Albanian High Court, No. 2, dated 03.11.2014.

Unifying Judgment of the Albanian High Court No. 980, dated 29.09.2000.

Judgment of the Civil Chamber of the High Court No. 169, dated 05.03.2013.

Judgment of the Appellate Court of Tirana No. 40, dated 23.02.2017.

Judgment of the Appellate Court of Tirana No. 32/1010, dated 01.03.2012.

Judgment of District Court of Tirana No. 7, dated 28.01.2019.

ECtHR 25th September 2012, Case No. 58555/10, Rrapo v Albania.

ECtHR 29 September 2009, Case No. 32907/07, Gjyli v Albania.

ECtHR 24 June 2014, Case No.1542/13, Becaj v Albania.

Case C-456/11, Gothaer Allgemeine Versicherung and others, ECLI:EU:C:2012:719.

\section{About the author}

Flutura Kola is a Professor of Civil Procedure Law and International Arbitration at the Faculty of Law, University of Tirana, Albania and Partner of “Kola \& Associates' Law Firm, e-mail: tafajf@yahoo.com. 